J. Asiat. Soc. Bangladesh, Sci. 44(1): 23-33, June 2018

\title{
EVALUATION OF DIFFERENT MUTANTS AGAINST INSECT AND MITE PESTS WITH NATURAL ENEMIES IN COASTAL JUTE ECOSYSTEM
}

\author{
M M H KHAN ${ }^{*}$ \\ Department of Entomology, Patuakhali Science and Technology University, \\ Dumki, Patuakhali-8602, Bangladesh
}

\begin{abstract}
Jute is a rapid growing agricultural fiber crop and renewable source of biomass. The study was conducted to evaluate different jute mutants against insect and mite pests with associated natural enemies. Results revealed that 8 insect and mite pests and 8 natural enemies were recorded from coastal jute ecosystem. Jute hairy caterpillar and yellow mite were found to be the most damaging pests in jute field. Significantly the lowest per cent plant infestation per 5 rows was recorded in mutant BJC-214 (14.37) followed by BJC-7370 (14.81) and the highest per cent plant infestation (30.77) was found in mutant VM-1. Significantly the lowest per cent leaf infestation was in mutant HC-3 (25.40) followed by HC-95 (31.08) while the highest per cent leaf infestation per plant was recorded in mutant BJC-83 (46.30). In case of leaf area damage, the lowest per cent was observed in mutant HC-3 (9) followed by CVL-1 (10) and the highest was in mutant CVE-3 (45) followed by mutant 0-72 (30). Among different mutants, HC-3, CVL-1 and BJC-214 were found to be less infested by jute hairy caterpillar and these mutants could be used for multilocational trial for final recommendation as the tolerant mutants.
\end{abstract}

Key words: Jute mutants, Insect pests, Jute hairy caterpillar, Natural enemies

\section{Introduction}

Bangladesh is one of the major jute producing countries where about $90 \%$ of the world's jute is produced. Jute (Corchorus spp.; Malvales: Malvaceae) and mesta (Hibiscus spp.; Malvales: Malvaceae) are natural plant fibers of commercial importance after cotton. Two species of jute viz., Corchorus capsularis L. and C. olitorius L. are the most important fibre crops, and these are extensively grown in Bangladesh as a cash crop. In here about $6,72,615$ hectares of land were under jute cultivation and the total production was about 75,01,011 bales in the year of 2014 - 2015 (BBS 2016). Several factors are responsible for the decrease of yield of jute, of which the loss due to insect pest is the major concern. Different harmful insects, mites and beneficial insects are found to occur in jute field from seedling stage to harvest. Forty species of insects and mites are considered to be the pests of jute in Bangladesh (Kabir 1975), of which jute hairy caterpillar (Spilarctia obliqua Wlk.), jute semilooper (Anomis sabulifera Guen), stem

\footnotetext{
${ }^{*}$ Email: mohasin1965@pstu.ac.bd
} 
weevil (Apion corchori Marshall), grey weevil (Myllocerus discolor Bohemus) and yellow mite (Polyphagotarsonemus latus Banks) were recorded as the major pests of jute. About $12 \%$ yield loss is caused by insect pests alone (Anon. 1987). Jute suffers a great loss in yield and quality of fibres due to the severe attack by the jute hairy caterpillar, Spilosoma obliqua (Walker) in the field during the jute growing season (Kabir and Khan 1969). The young caterpillars remain in clusters up to 3rd instar and feed on the lower epidermis of leaves, but from the fourth instar they spread over the field, eat up whole leaf tissues leaving only ribs, and thus adversely affect the yield of jute fibre. Besides jute, this insect was also found to attack sunflower, pulse, groundnut, radish and soybean, cotton, brinjal, cabbage, cauliflower, linseed, peas and many leguminous plants (Mallik et al. 1996, Kabir 1966). The jute semilooper, a cosmopolitan pest, is reported from the entire jute growing region all over the world and has estimated to damage up to $90 \%$ of the leaves of jute plant in some cases (Tripathi and Ghose 1964). Damage to jute foliage results in poor plant growth and ultimately low fibre quantity (Tripathi and Ghose 1964, Sing and Das 1979, Das and Sing 1976, Das et al. 1995). In general the pest of second generation is comparatively more destructive to the fibre crop (Sing and Das 1979) and in $81 \%$ cases the 7 - 9 leaves of upper part of the standing crop are damaged (Dutta 1958). In some cases the extent of damage may extend up to $91 \%$ covering 9 th position of the leaf of the tiller. Pre monsoon rains followed by drought condition are congenial for the outbreak of semilooper and may lead up to 50\% loss of crop as reported by Dutta (1958). Yellow mite (Polyphagotarsonemus latus Banks) and red mite (Oligonychus coffeae Nietner) are considered as the other major pests (Das and Sing 1977) in India, are destructive pests and attack both the cultivated jute species (Martinez and Mendez 1994, Roe et al. 1996, Karmakar 1997, Chakravarthy et al. 1998). The damage of yellow mite is generally known as "Telenga" or Telchita". The infestation usually appears on the apical leaves and a reduction of $10-17 \%$ fibre yield may be caused (Ahmed and Jalil 1993). Different methods viz., cultural, mechanical, biological and chemical are used to control jute pests but none of them provides effective and sound control. Farmers apply high doses of inorganic fertilizers and different types of toxic and hazardous type of newer insecticides in high quantum without any concern to the environment (Das and Sing 1986). In addition to that continuous and heavy use of synthetic insecticides creates several problems, including pesticide resistance (Rustanmani et al. 1985, Duguet and Wu 1986), and health hazards (Bhaduri et al. 1989). Primarily, chemicals of same group and in higher concentration affect other crop field and nearby crop ecosystem and it will make unquestionably more resistant pest in future because of the applied higher concentration. Secondly, several new chemicals with novel mode of action are available in market, but it may not be suitable unless their field efficiency and baseline data for toxicity is generated (RPMN 2007). Further, use of synthetic chemical insecticides 
although successfully control the pest(s), it destroy predators, parasitoids and beneficial microbes causing imbalance in the ecosystem. The jute ecosystem supports large number of natural enemies of crop pests (Rahman and Khan 2009) and their importance in integrated approach for management of pests of jute has been developed (Rahman and Khan 2010). Therefore, it is urgent need to find out eco-friendly alternative approach for the management of jute pests. Considering the above facts the present research program was under taken to evaluate some jute mutants against jute hairy caterpillar and yellow mite and to know the incidence of insect pest and mite with associated natural enemies on these mutants in coastal jute ecosystem.

\section{Materials and Methods}

The experiment was conducted under natural field conditions at agricultural farm of Patuakhali Science and Technology University (PSTU), Dumki, Patuakhali during May to September, 2012. The experimental field was high land with sandy loam texture belonging to the Ganges Tidal Floodplain (AEZ 13). Twelve advanced mutants/lines viz., 0-9897, 0-72, 0-795, HC-2, HC-3, HC-95, BJC-83, BJC-214, BJC-7370, CVL-1, CVE-3 and VM-1 (715) were used as study materials to evaluate against jute hairy caterpillar and yellow mite and also to know the incidence pattern of insect pest with associated natural enemies. The experiment was laid out in randomized complete block design with three replications. The size of the individual plot was $4 \mathrm{~m} \times 2.5 \mathrm{~m}$ and spacing between plot to plot and line to line was $0.5 \mathrm{~m}$ and $0.3 \mathrm{~m}$, respectively. Seeds of 12 advanced mutants/lines of jute were collected from Bangladesh Jute Research Institute for conducting this experiment. The seeds were sown after final land preparation. All the agronomic practices including land preparation, sowing of seeds, fertilizer application and intercultural operations were done in raising the crop by the farm labours under constant supervision. Incidence of insect pests with associated natural enemies was recorded from seedling to harvesting. Infestations of jute plants under natural field condition were recorded at 60 days after sowing (DAS). Infested and uninfested plants and leaves were collected from five randomly selected rows of each plot to determine the level of infestation. The total number was counted and percentage of infested plants was calculated. The percentage of leaf infestation per plant was calculated again from five randomly selected plants. The percentage of leaf area damaged by jute hairy caterpillar was determined by eye estimation. The percentage of infestation was calculated by the following formula.

Percentage of plants or leaves infested $=\frac{\mathrm{B}}{\mathrm{A}} \times 100$ 
where, $A=$ Number of total plants or leaves,

$B=$ Number of infested plants or leaves

Data obtained from the experiment were statistically analyzed following ANOVA by using MSTAT-C programme and means were compared by DMRT.

\section{Results and Discussion}

Incidence of insect pests and natural enemies: As jute is grown during the summer season, a number of insect pests infest throughout the crop cycle. Insect pests viz., jute hairy caterpillar, jute semilooper, stink bug, hooded hopper, field cricket, sulphur butterfly, leaf eating caterpillar, red pumpkin beetle and ants were found to infest different mutants of jute after 60 DAS. Among them, jute hairy caterpillar was dominant and devastating. Beside these, jute yellow mite caused damage to the leaves of jute mutants. Similarly, the jute agro-ecosystem supports large number of natural enemies. Natural enemies viz., lady bird beetle, ground beetle, damsel fly, dragon fly, house fly, rove beetle, wasp and spider were observed on different mutants in jute ecosystem. Among them, lady bird beetle, spider and dragon flies were the most abundant (Ttable 1). In general 40 species of insects and mites attack on jute in Bangladesh as reported by Kabir (1966). Das and Sing (1986) and Rahman and Khan (2012) had enlisted a profile of insect pests in relation to the growth stage of the jute plant damaging jute crop. Rahman and Khan (2012) recorded 70 different species of pest belong to insects, mites and nematodes feeding on jute which appeared at different growth stages of jute in two consecutive years of observations.

Out of this, jute hairy caterpillar Spilarctia (= Spilosoma) obliqua (Walker) is of prime importance (Kabir and Khan 1968). Apart from jute hairy caterpillar, jute semilooper (Anomis sabulifera Guen.), Bihar hairy caterpillar (Spilarctia obliqua Wlk.), indigo caterpillar (Spodoptera exigua Hubner), stem girdler (Nupserha bicolor Dutt), stem weevil (Apion corchori Marshall), grey weevil (Myllocerus discolor Bohemus), yellow mite (Polyphagotarsonemus latus Banks) and red mite (Oligonychus coffeae Nietner) were recorded on olitorius jute var. JRO-54 from seedling to harvest stages of jute crop in India (Das and Sing 1977). Rahman and Khan (2012) observed Grey weevil (Myllocerus discolor) as a voracious feeder of tender leaves of jute seedlings during 2nd week of May and remained active throughout the crop season with peak infestation of $33.56 \%$ plant damage and 36\% leaf damage in the first week of June in 2004. Rahman and Khan (2010) has been developed the importance of natural enemies in integrated approach for management of pests of jute. 
Table 1. Incidence of insect pests and natural enemies on different mutants of Jute at Dumki, Patuakhali during May to September, 2012.

\begin{tabular}{|c|c|c|c|c|}
\hline $\begin{array}{l}\text { Sl. } \\
\text { No. }\end{array}$ & Common name & Scientific name & Family & Order \\
\hline & \multicolumn{4}{|c|}{ Insect and mite pests } \\
\hline 1 & $\begin{array}{l}\text { Jute hairy } \\
\text { caterpillar }\end{array}$ & Spilarctia obliqua Walk. & Arctiidae & Lepidoptera \\
\hline \multirow[t]{3}{*}{2} & Jute semilooper & Anomis sabulifera Guen. & Noctuidae & lepidoptera \\
\hline & Jute stem weevil & Apion corchori Marshall & Curculionidae & Coleoptera \\
\hline & Jute grey weevil & $\begin{array}{l}\text { Myllocerus discolor } \\
\text { Bohemus }\end{array}$ & Curculionidae & Coleoptera \\
\hline \multirow[t]{2}{*}{3} & Hemipteran bug & Unidentified & Pentatomidae & Hemiptera \\
\hline & Hooded hopper & Otinotus elongates Kif & Cercopidae & Hemiptera \\
\hline 4 & Field cricket & Brachytrypes portentosus & Gryllidae & Orthoptera \\
\hline 5 & Sulphur butterfly & Unidentified & Pieridae & Lepidoptera \\
\hline 6 & $\begin{array}{l}\text { Red pumpkin } \\
\text { beetle }\end{array}$ & Aulacophora sp. & Chrysomelidae & Coleoptera \\
\hline 7 & Ant & Camponotus compressus & Formicidae & Hymenoptera \\
\hline 8 & Yellow mite & $\begin{array}{l}\text { Polyphagotarsonemus latus } \\
\text { Banks }\end{array}$ & Tarsonemidae & Acarina \\
\hline \multicolumn{5}{|c|}{ Natural enemies } \\
\hline \multirow[t]{2}{*}{1} & Lady bird beetle & Micraspis discolor & Coccinellidae & Coleoptera \\
\hline & Lady bird beetle & Coccinella septempunctata & Coccinellidae & Coleoptera \\
\hline 2 & Ground beetle & Ophionea nigrofasciata & Carabidae & Coleoptera \\
\hline 3 & Damselfly & Unidentified & Coenagrionidae & Odonata \\
\hline 4 & Dragonfly & Unidentified & Ashnidae & Odonata \\
\hline 5 & Wasp & Unidentified & Vespidae & Hymenoptera \\
\hline 6 & Spiders & Oxyopes spp. & Lycosidae & Araneae \\
\hline 7 & Assasin bug & Zelus longipes L. & Reduvidae & Hemiptera \\
\hline 8 & Rove beetle & Holobus kashmiricus & Staphylinidae & Coleoptera \\
\hline
\end{tabular}

Percentage of jute plant infested by hairy caterpillar: The percentage of jute plants per 5 rows infested by jute hairy caterpillar on different mutants is presented in Table 2. Significantly the highest per cent plant infestation per 5 rows (30.77) was found in mutant VM-1 followed by 0 - 9897 (30.37) which was statistically similar to 0 - 72 (30.22) and HC-95 (29.91) followed by CVL-1 (22.32). Significantly the lowest per cent plant infestation was recorded in mutant BJC-214 (14.37\%) followed by BJC-7370 (14.81) and HC-3 (14.86). However, no significant difference was observed on plant infestation among mutant HC-2 (17.71\%), BJC-83 (16.09\%) and 0-795 (15.65\%). The rank order of plant infestation per 5 rows was VM-1 $>0-9897>0-72>$ HC-95 $>$ CVL-1 $>$ CVE-3 $>$ HC-2 $>$ BJC-83 $>0-795>$ HC-3 $>$ BJC-7370 $>$ BJC-214. 
Table 2. Percentage of jute plants infested by jute hairy caterpillar on different mutants.

\begin{tabular}{lcccc}
\hline Mutants & $\begin{array}{c}\text { Total number of plants } \\
\text { checked/5 rows }\end{array}$ & $\begin{array}{l}\text { Number of } \\
\text { infested plants }\end{array}$ & $\begin{array}{l}\text { Number of } \\
\text { healthy plants }\end{array}$ & $\begin{array}{c}\% \text { infested } \\
\text { plants/ 5 rows }\end{array}$ \\
\hline $0-9897$ & 135 & 41 & 94 & $30.37 \mathrm{ab}$ \\
$0-72$ & 278 & 84 & 194 & $30.22 \mathrm{ab}$ \\
$0-795$ & 115 & 18 & 97 & $15.65 \mathrm{~d}$ \\
HC-2 & 96 & 17 & 79 & $17.71 \mathrm{~d}$ \\
HC-3 & 148 & 22 & 126 & $14.86 \mathrm{de}$ \\
HC-95 & 107 & 32 & 75 & $29.91 \mathrm{ab}$ \\
BJC-83 & 230 & 37 & 193 & $16.09 \mathrm{~d}$ \\
BJC-214 & 174 & 25 & 149 & $14.37 \mathrm{e}$ \\
BJC-7370 & 135 & 25 & 115 & $14.81 \mathrm{de}$ \\
CVL-1 & 112 & 82 & 87 & $22.32 \mathrm{bc}$ \\
CVE-3 & 394 & 52 & 312 & $20.81 \mathrm{~cd}$ \\
VM-1 & 169 & & 117 & $30.77 \mathrm{a}$ \\
CV (\%) & & & & 17.64 \\
CD $(5 \%)$ & & & & 6.403 \\
\hline
\end{tabular}

Values are averages of three replications.

Percentage of infested leaves per plant: Percentage of jute leaves infested by jute hairy caterpillar on different mutants is presented in Table 3. Significantly the highest per cent leaf infestation per plant was recorded on mutant BJC-83 (46.30\%). The lowest per cent leaf infestation was in mutant HC-3 (25.40) followed by HC-95 (31.08) which was statistically similar to BJC-214 (34.48), 0-795 (35.19). Statistically identical results were found in CVL-1 (36.54\%) and BJC-7370 (36.54\%). However, no significant differences were observed among mutants VM-1, CVE-3, HC-2, 0-72 and 0-9897 (Plate 1 and 2). The rank order of per cent leaf infestation per plant was BJC-83 $>0-9897$ $>0-72>$ HC-2 > CVE-3 > VM-1 > BJC-7370 $\geq$ CVL-1 $<0-795>$ BJC-214 > HC-95 > HC-3.

Table 3. Percentage of jute leaves infested by jute hairy caterpillar in different mutants.

\begin{tabular}{|c|c|c|c|}
\hline Mutants & $\begin{array}{l}\text { Total number of leaves/ } \\
\text { plant }\end{array}$ & $\begin{array}{l}\text { Number of infested } \\
\text { leaves/plant }\end{array}$ & $\begin{array}{l}\% \text { infested } \\
\text { leaves/plant }\end{array}$ \\
\hline $0-9897$ & 10.6 & 4.6 & $43.40 \mathrm{ab}$ \\
\hline $0-72$ & 10.2 & 4.2 & $41.18 \mathrm{ab}$ \\
\hline $0-795$ & 10.8 & 3.8 & 35.19ab \\
\hline $\mathrm{HC}-2$ & 13.8 & 5.6 & $40.58 \mathrm{ab}$ \\
\hline $\mathrm{HC}-3$ & 12.6 & 3.2 & $25.40 \mathrm{~b}$ \\
\hline HC-95 & 14.8 & 4.6 & $31.08 \mathrm{ab}$ \\
\hline BJC-83 & 10.8 & 5.0 & $46.30 \mathrm{a}$ \\
\hline BJC-214 & 11.6 & 4.0 & $34.48 \mathrm{ab}$ \\
\hline BJC-7370 & 10.4 & 3.8 & $36.54 \mathrm{ab}$ \\
\hline CVL-1 & 10.4 & 3.8 & $36.54 \mathrm{ab}$ \\
\hline CVE-3 & 12.0 & 4.8 & $40.00 \mathrm{ab}$ \\
\hline VM-1 (715) & 8.2 & 3.2 & $39.02 \mathrm{ab}$ \\
\hline CV (\%) & & & 21.30 \\
\hline $\mathrm{CD}(5 \%)$ & & & 5.501 \\
\hline
\end{tabular}

Values are averages of 5 observations. 
Percentage of leaf area damaged by hairy caterpillar: Fig. 1 revealed that the highest per cent leaf area damaged was observed in mutant CVE-3 (45) followed by mutant 0-72 (30) which was statistically identical to BJC-7370 (30) and the lowest was in mutant HC-3 (9) followed by CVL-1 (10), HC-95 (12) and BJC-83 (15). The intermediate higher level of leaf area damage was found in mutant 0-795 (17\%) followed by BJC-214 (18\%), HC-2 (22\%) and 0-9897 (25\%) which was statistically identical to VM-1 (715) (25\%). The rank order of leaf area damage was CVE-3 $>$ BJC-7370 $\geq 0-72>0-9897 \geq \mathrm{VM}-1(715)>$ HC-2 > BJC-214 > 0-795 > BJC-83 > HC-95 > CVL-1 > HC-3.

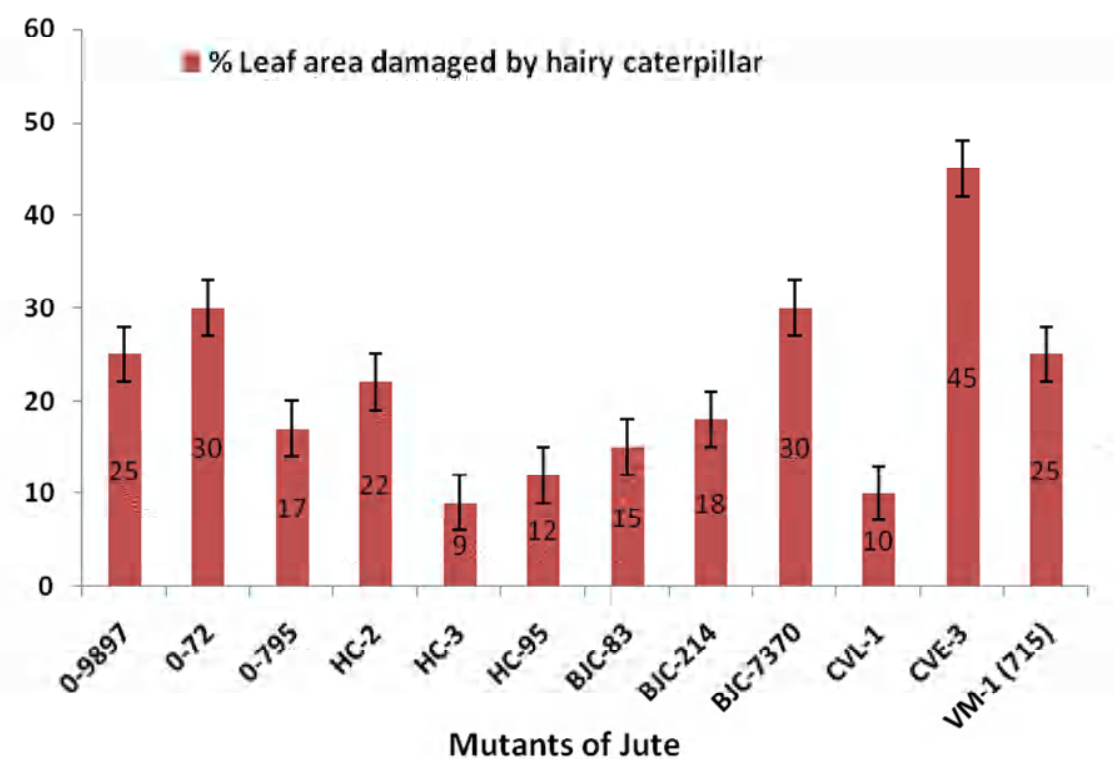

Fig. 1. Percentage of leaf area damaged by jute hairy caterpillar on jute mutants.
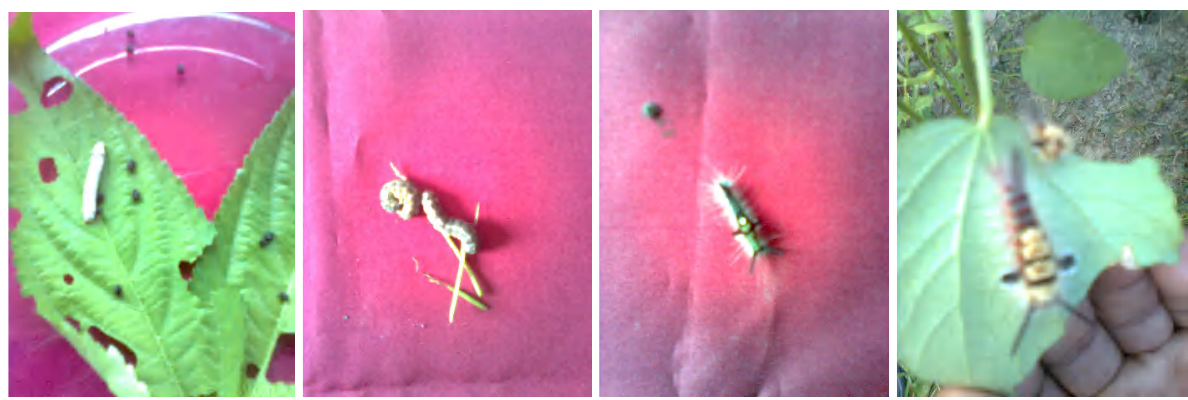

Fig. 2. Different immature stages of jute hairy caterpillar. 


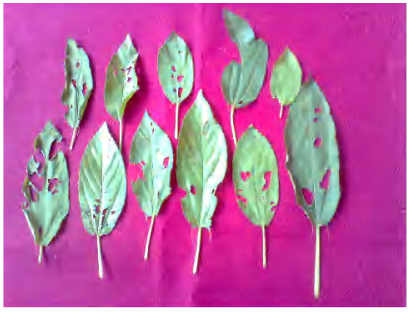

0-9897

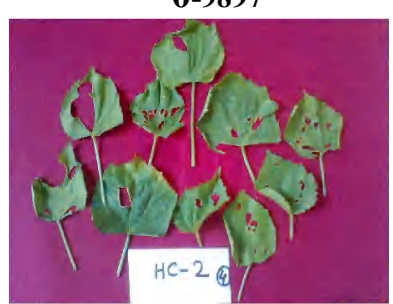

HC-2

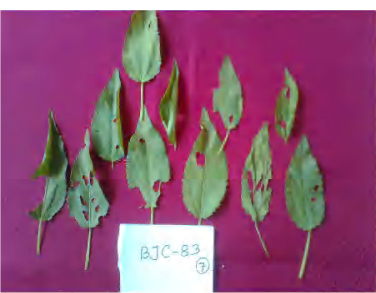

BJC-83

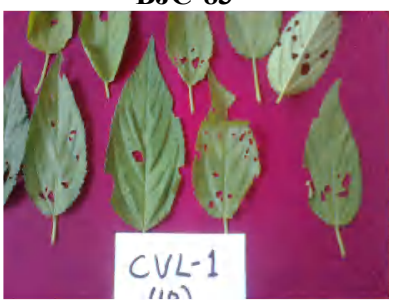

CVL-1

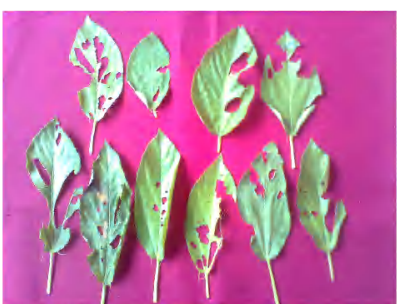

0-72

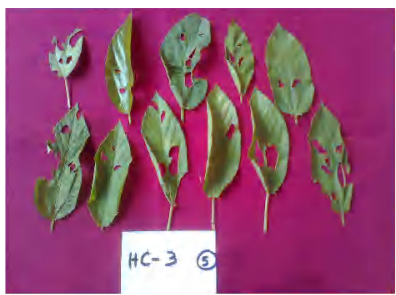

HC-3

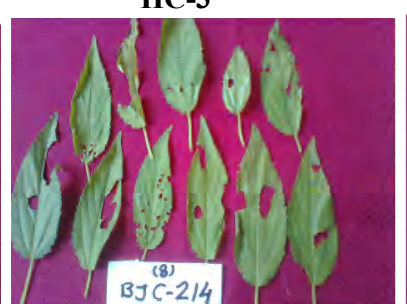

BJC-214

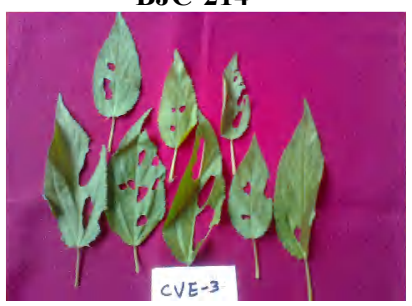

CVE-3

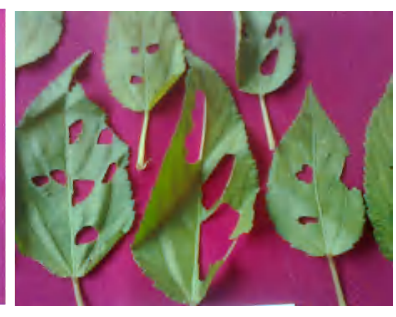

0-795

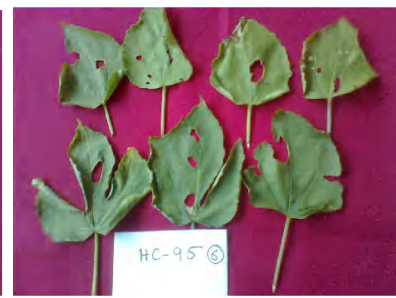

HC-95

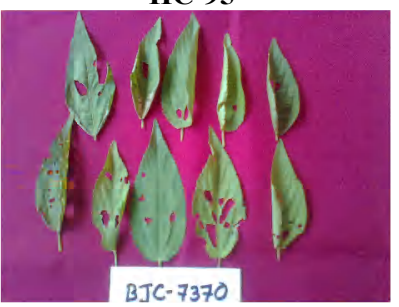

BJC-7370

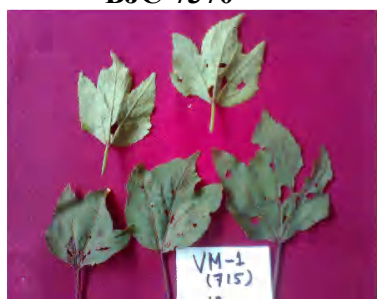

VM-1(715)

Fig. 3. Damaged leaves of different mutants caused by jute hairy caterpillar.

Damage symptoms of yellow mite (Polyphagotarsonemus latus Banks): The damage of yellow mite is generally known as "Telenga" or Telchita". The infestation usually appears on the apical leaves of jute plant (Fig. 4). Rahman and Khan (2012) observed that yellow mite incidence was started in the last week of May and attained its peak with $29.33 \%$ plant infestation and 35.87 mites/leaf in the last week of June, 2004 and $27.60 \%$ plant infestation with 18.66 mites/leaf in the 3rd week of June 2005. 
Yellow mite, Polyphagotarsonemus latus is destructive for jute production (Das and Rouchaudhori 1979). They suck sap from younger leaves results in foliage discoloration; natural green colour of leaves turn into brown with change of shape due to curling (Das and Sing 1985). Loss of nutrition in young plant due to sucking, height of the plant becomes stunted and significant yield loss occurs (Nair 1986, Pradhan and Saha 1997).
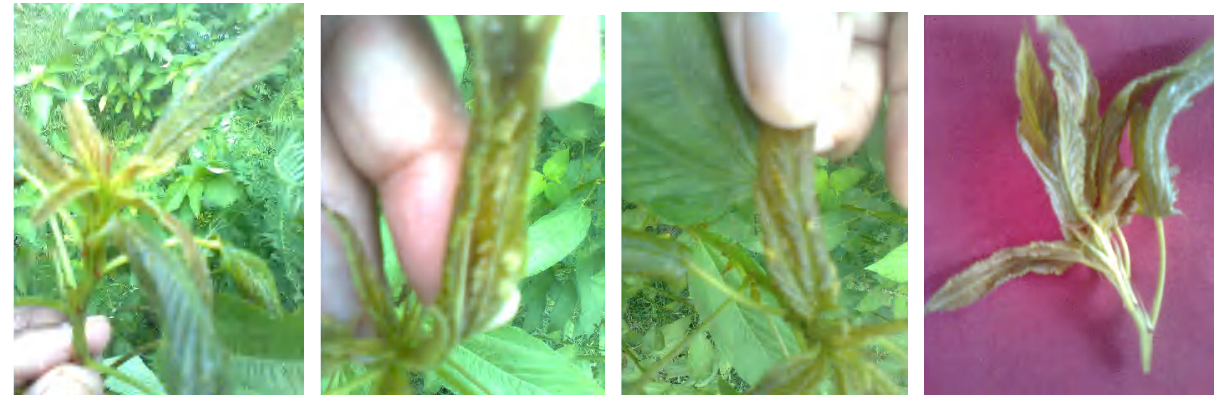

Fig. 4. Damage symptoms due to yellow mite infestation in jute.

Rahman and Khan (2012) reported that S. obliqua infestation was noticed in the second week of June with $5.63 \%$ plant infestation and reached its peak infestation with $21.6 \%$ in the 2 nd week of July and declined thereafter to cause $2.96 \%$ plant infestation in the last week of July in 2004. No hairy caterpillar larvae were found during harvest of the jute. Rahman and Khan (2010) reported from a pest complex of olitorius jute var. JRO-524 that incidence of $S$. obliqua, A. sabulifera, M. discolor, A. corchori and P. latus causing a minimum of $4.68,6.10,12.38,5.09$ and $10.47 \%$ plant infestation, respectively. Mahapatra (1996) found that yellow mite incidence started in the last week of May and continued up to July with $9.01-49.71 \%$ plant infestation and number of mites/leaf varied from 37.6 to 91.3. Das and Pathak (1999) reported a maximum of 77.39 yellow mites/leaf in C. olitorius jute and 16.00 mites/leaf in C. capsularis jute varieties.

\section{Acknowledgements}

The author is grateful to the Department of Agronomy and Agriculture farm, Patuakhali Science and Technology University, Dumki, Patuakhali for planting of different jute mutants, crop management and providing facilities to carry out the entomological work.

\section{References}

Ahmed, T.U. and A.F.M.A. Jalil 1993. Bangladesher Krishir Onistakari Pokamakar, Jibon Bittanta O Niyuntran (life history and control of insects harmful to Bangladesh Agriculture). 1st edition. Bangladesh Academy, Dhaka. pp. 131-201.

Anonymous. 1987. Technological advancement in jute cultivation. 1st edition. Bangladesh Jute research Institute (BJRI), Dhaka. $36 \mathrm{pp}$. 
BBS, 2016. Bangladesh Bureau of Statistics, Yearbook of Agricultural Statistics-2015, 27th Series, Statistics and Information Division, Ministry of Planning, Government of the People's Republic of Bangladesh.

Bhaduri, N., D.P. Gupta and S. Ram 1989. Effect of vegetable oil on the ovipositional behavior of Callosobruchus maculatus (Fab.) Proc. 2nd Int. Symp. on Bruchids and legumes (ISBL-2) held at Okayama (japan), Sept 6-9, 1989, pp. 81-84.

Chakravarthy, A.K., S.V. Ravi and C. Somashekar 1998. Monitoring of insects and mites on potato (Solanum tuberosum). Rev. Agril. Entomol. 86(12): 1503.

Das, L.K. and D.N. Roychaudhori 1979. Physalis minima - A new host plant of yellow mite, Polyphagotar sonenus latus (Banks). Sci. \& Cult. 43:169-170.

Das, L.K. and S. Pathak, 1999. Resistance behaviour of some jute varieties against their pests. Environ. Ecol. 17(2): 456-457.

Das, L. K. and B. Sing, 1976. The effect of Bacillus thuringiensis Berliner on the gut of the jute semilooper, Anomis sabulifera Guen. Sci. \& Cult. 42: 567-569.

Das, L.K. and B. Sing, 1977. Economic control measures against the major pests of jute, PANS, 23: $159-161$.

Das, L.K. and B. Sing, 1985. Number of sprays suitable against yellow mite, P. latus (Bank) of jute, Sci. \& Cult. 51:376-377.

Das, L. K. and B. Sing, 1986. Effective control measures against the pest complex of capsularia jute Corchorus capsularis L. Jute Development J. 25-27.

Das, L. K., B. Sing and S. K. Pradhan 1995. Efficiency of different synthetic pyrethroids insecticides against pest complex of jute. Sci. \& Cult. 61: 203-204.

Duguet, J.S. and G.X. WU 1986. Assessment of activity of deltamethrin against Callosobruchus chinensis L. and Callosobruchus maculatus Fab. (Bruchidae). Int. Pest Control. 28(2), 36-41.

Dutta, N. 1958. Anomis sabulifera Guen., Apion corchori Marsh-Insecticides and control. Jute Bulletin. 121-128.

Kabir, A.K.M.F. 1966. Phase variation in the jute hairy caterpillar, Diacrisia obliqua Walk. (Lepidoptera: Arctiidae). Sindney Univ. Sci. J. 11: 1-3.

Kabir, A.K.M.F. and S.A. Khan 1968. Bioassay of some insecticides for the control of jute hairy caterpillar; Diacrisia obliqua Walker., Indian J. Agric. 6(1-2): 131-138.

Kabir, A.K.M.F. and S.A. Khan 1969. Biology and life history of jute hairy caterpillar, Diacrisia obliqua Walker, in East Pakistan. Pakistan J. Zool. 1(1): 45-48.

Kabir, A.K.M.F. 1975. Jute pest of Bangladesh. Bangladesh Jute research Institute. Dacca. 15. pp. 28-36.

Karmakar, K. 1997. Size, shape and behavior of Polyphagotarsonemus latus Banks (Acarina: Tarsonemidae). Rev. Agril. Entomol. 85(12): 1494.

Mallik, M. U., M.S., Islam, S.A. Khan and M.A.I. Bhuiyan 1996. Studies on over wintering sites, laboratory rearing, mating behavior and population build up of Spilosoma obliqua Walker. Working materials, IAEA D4-RC-561.

Martinez, G. and G. Mendez, 1994. The white mite, Polyphagotarsonemus latus Banks (Acarina: Tarsonemidae) in tobacco cultivation in the province of villa Clara, Rev. Agril. Entomol. 84(8): 939.

Mohapatra, L. N. 1996. Response of jute (Corchorus capsularis L.) germplasm against yellow mite, Polyphagotarsonemus latus Banks (Acarina: Tarsonemidae) in coastal region of Orissa. Rev. Agril. Entomol. 84(11): 1307.

Nair, M.R.G.K. 1986. Insects \& mites of crop in India. ICMR. New Delhi. 122 -126.

Pradhan, S.K. and M.N. Saha, 1997. Effect of yellow mite, P. Latus (Bank) infestation on the major nutrient contents of tossa jute (Corchorus olitorius L.) verities, J. Entomol. Res. 21: 123-127.

Rahman, S. and M.R. Khan 2009. Natural enemies of insect and mite pests of jute ecosystem. Ann. Plant Prot. Sci. 17(2): 466-467.

Rahman, S. and M.R. Khan 2010. Integrated management approach for control of the pest complex of Olitorius jute corchorus olitorius. J. Plant Proct. Sci. 50(3): 340-346. 
Evaluation of different mutants against insect and mite pests

Rahman, S. and M.R. Khan 2012. Incidence of pests in jute (Corchorus olitorius L.) ecosystem and pest - weather relationships in West Bengal, India. Archives of Phytopathology and Plant Protection. 45(5):591-607.

Roe, C.M., J.H. Yung, and D.K. Soon 1996. Host plant and damage of broad mite, Polyphagotarsonemus latus Banks on Horticultural crops in korea, Rev. Agril. Entomol. 85(3): 333.

RPMN. 2007. Need for resistance risk assessment in major pest of jute to insecticides, Resistance Management Review, Resistance Pest Management Newsletter. 17(1): 1-4.

Rustanmani, M.A., S.M.S.H. Naqvi and G.H. Abro 1985. Relative resistance/susceptibility of different pulses against pulse beetle, Callosobruchus chinensis L. Pak. J. Zool. 17(1): 99100.

Sing, B. and L. K. Das 1979. Semilooper, Anomis sabulifera Guen. escalating on jute pods. Sci. \& Cult. 45: 121-123.

Tripathi, R. L. and S. K. Ghose 1964. Studies on prophylactic and curative measures against jute semilooper, Anomis sabulifera Guen. (Lepidoptera: Noctuidae). Jute Bulletine. 75-77.

(Revised copy received on 5.4.2018) 